\title{
Environmental exposures and mechanisms in allergy and asthma development
}

\author{
Liza Bronner Murrison, ${ }^{1,2}$ Eric B. Brandt, ${ }^{1}$ Jocelyn Biagini Myers, ${ }^{1,2}$ and Gurjit K. Khurana Hershey ${ }^{1,2}$ \\ 'Division of Asthma Research, Cincinnati Children's Medical Center, Cincinnati, Ohio, USA. ²Department of Pediatrics, University of Cincinnati College of Medicine, Cincinnati, Ohio, USA.
}

\begin{abstract}
Environmental exposures interplay with human host factors to promote the development and progression of allergic diseases. The worldwide prevalence of allergic disease is rising as a result of complex gene-environment interactions that shape the immune system and host response. Research shows an association between the rise of allergic diseases and increasingly modern Westernized lifestyles, which are characterized by increased urbanization, time spent indoors, and antibiotic usage. These environmental changes result in increased exposure to air and traffic pollution, fungi, infectious agents, tobacco smoke, and other early-life and lifelong risk factors for the development and exacerbation of asthma and allergic diseases. It is increasingly recognized that the timing, load, and route of allergen exposure affect allergic disease phenotypes and development. Still, our ability to prevent allergic diseases is hindered by gaps in understanding of the underlying mechanisms and interaction of environmental, viral, and allergen exposures with immune pathways that impact disease development. This Review highlights epidemiologic and mechanistic evidence linking environmental exposures to the development and exacerbation of allergic airway responses.
\end{abstract}

\section{Background}

Environmental exposures can dramatically influence the phenotype of allergic diseases, including atopic eczema, food allergy, asthma, and allergic rhinitis (1-4). These diseases now affect approximately $20 \%$ of the population worldwide $(4,5)$; yet the prevalence has increased too rapidly in recent decades to be explained by genetic changes alone $(1,6)$. The International Study of Asthma and Allergies in Childhood has demonstrated that the prevalence of these diseases can be very high in settings with low socioeconomic conditions and can vary greatly between regions, countries, and centers within a city or country, indicating the role of local environmental characteristics $(7,8)$. Global trends of increasing urbanization and rapid population growth contribute to changes in lifestyle (diet, time indoors, physical activity) and environmental exposures (air pollution, smoking, mold, infections) that affect atopic allergic mechanisms and rising disease prevalence worldwide (1, 2, 9-11). Many of these changes are associated with early-life and lifelong risk factors for the development and exacerbation of asthma and atopic allergic diseases.

The terms "allergy" and "atopy" are often used to describe IgE-mediated diseases wherein persons with atopy are predisposed to produce IgE antibodies against common environmental allergens and have one or more atopic allergic diseases (i.e., atopic eczema, food allergy, asthma, and allergic rhinitis), though some nonatopic allergic diseases (e.g., nonatopic asthma, contact dermatitis) develop through IgE-independent mechanisms (4). The interplay of genetic predispositions and environmental exposures is instrumental in shaping the immune system, espe-

Conflict of interest: The authors have declared that no conflict of interest exists. Copyright: (๑) 2019 American Society for Clinical Investigation

Reference information: / Clin Invest. 2019;129(4):1504-1515.

https://doi.org/10.1172/JCI124612. cially in early life when neonates go from limited environmental exposure in utero to having their skin, lungs, and intestinal tract colonized by fungus and bacteria to form their microbiome. It is increasingly recognized that the timing and route of exposure affect allergic disease development $(1,6)$. An impaired skin barrier represents an important route of entry for allergens, bacteria, viruses, air pollutants, and environmental chemicals leading to epicutaneous sensitization, atopic dermatitis, and/or asthma in susceptible children (12-16).

In this context, it is useful to consider three types of exposures: (a) the external outdoor environment; (b) the indoor environment; and (c) host environmental factors. Many early-life exposures and physiological mechanisms not included in this Review have been linked to allergic disease development, including lifestyle factors, obesity, pre- and postnatal maternal psychological stress, pharmaceuticals, occupational exposures, chemical pollutants, and more. In addition to varying by host response, geographic regions, and socioeconomic status, these exposures likely interact simultaneously to affect allergic mechanisms such that no one factor dictates disease development in all subjects. This Review summarizes the epidemiologic and mechanistic evidence linking environmental exposures to the development and exacerbation of atopic asthma and allergic responses.

\section{Microbial exposures}

Adoption of a Western lifestyle corresponds to environmental, behavioral, and dietary changes characterized by increased time spent indoors, antibiotic usage, obesity prevalence, and decreased physical activity and siblings per family. The hygiene hypothesis theorizes that increased exposures to early-life infections and larger family size lead to decreased risk of allergic disease development (17). Alternatively, the "old friends" hypothesis proposes that increases in allergic diseases are due to the loss of symbiotic relationships with parasites and bacteria that were once beneficial 


\section{Table 1. Consistently observed environmental effects associated with allergic diseases in epidemiologic studies ${ }^{\mathrm{A}}$}

\begin{tabular}{|c|c|c|c|c|}
\hline Exposure or risk factor & Clinical phenotype & Study type & No. of studies & Age group \\
\hline $\begin{array}{l}\text { Environmental microbial } \\
\text { exposures }\end{array}$ & $\begin{array}{l}\text { Microbiome diversity, } \\
\text { atopy, asthma }\end{array}$ & $\begin{array}{c}\text { Review; } \\
\text { cross-sectional }\end{array}$ & 2 & $6-13$ years \\
\hline $\begin{array}{l}\text { Dogs and cats (dog and cat } \\
\text { exposure and ownership) }\end{array}$ & $\begin{array}{c}\text { Asthma, } \\
\text { sensitization }\end{array}$ & $\begin{array}{l}\text { NHANES } \\
\text { cross-sectional; } \\
\text { cohort }\end{array}$ & $1 ; 1$ & $1-69$ years \\
\hline
\end{tabular}

\begin{tabular}{|c|c|c|c|c|}
\hline $\begin{array}{l}\text { Mold (mold odor and } \\
\text { visibility, dampness } \\
\text { damage) }\end{array}$ & $\begin{array}{l}\text { Asthma, } \\
\text { allergic rhinitis }\end{array}$ & $\begin{array}{l}\text { Meta-analyses; } \\
\text { birth cohort }\end{array}$ & $27 ; 2$ & Birth-44 years \\
\hline
\end{tabular}

\section{Consistent findings}

Decrease in environmental symbiosis with parasites/bacteria and microbiome diversity influences immunoregulation, increases allergy and asthma prevalence (18)

Exposure to diverse microbes inversely related to risk of asthma (PARSIFAL, OR 0.62, 0.44-0.89; CABRIELA, 0.86, 0.75-0.99) (21)

Dog and cat allergen exposure and sensitization associated with risk and protective effects for developing allergic disease $(37,39)$

Early-life dog or cat ownership reduced sensitization to $\geq 1$ aeroallergen (dog, OR 0.65 , $0.45-0.95$; cat, $0 R$ 0.87, 0.73-1.04) and decreased asthma risk in children (dog, OR $0.87,0.81-0.93)(37)$

Increased asthma attack prevalence attributable to dog allergen among dog-sensitive $(44.2 \%)$ and cat allergen among cat-sensitive (30.3\%) (39)

Exposure to Cladosporium, Alternaria, Aspergillus, and Penicillium species increased asthma symptom exacerbation $36 \%-48 \%$ (43)

Mold or dampness indicator exposure during infancy increased risk of allergic asthma (OR 1.31, 1.08-1.59) and rhinitis (OR 1.29, 1.03-1.62), and nonallergic asthma (OR 1.80, $1.27-2.55)$ and rhinitis (OR 1.41, 1.03-1.93), up to 16 years of age (45)

$\begin{array}{lllll}\begin{array}{l}\text { Viral infections } \\ \text { (HRV, RSV) }\end{array} & \begin{array}{c}\text { Wheezing } \\ \text { and asthma }\end{array} & \text { Meta-analyses } & 15 & \text { Birth-18 years } \\ & & & \end{array}$

HRV-induced wheezing is more robust marker of asthma risk than RSV/other infectioninduced wheezing (67)

HRV wheezing illness in first $3,<10$, and $\geq 10$ years increased asthma risk in later life ( $\leq 3 \mathrm{yr}, \mathrm{RR} 2.00,1.62-2.49$; $<10 \mathrm{yr}, \mathrm{RR} 2.02,1.70-2.39$; $\geq 10 \mathrm{yr}, \mathrm{RR} 1.92,1.36-2.72$ ) (69)

\begin{tabular}{|c|c|c|c|c|}
\hline $\operatorname{TRAP}\left(\mathrm{BC}, \mathrm{NO}_{2}, \mathrm{PM}_{2.5}, \mathrm{PM}_{10}\right)$ & $\begin{array}{l}\text { Allergy, sensitization, } \\
\text { eczema, allergic } \\
\text { rhinitis, asthma }\end{array}$ & Meta-analyses & $5-15$ & Birth-18 years \\
\hline $\begin{array}{l}\text { Tobacco smoke } \\
\text { (secondhand smoke, } \\
\text { pre- or postnatal, } \\
\text { household) }\end{array}$ & $\begin{array}{l}\text { Wheeze, asthma, } \\
\text { sensitization, } \\
\text { eczema }\end{array}$ & $\begin{array}{l}\text { Meta-analyses; } \\
\text { birth cohort }\end{array}$ & $71 ; 1$ & Birth-18 years \\
\hline
\end{tabular}

Childhood TRAP exposure increases risk for development or exacerbation of atopy, sensitization, eczema, and asthma (91, 109, 111)

Increased risk of asthma development associated with BC (OR 1.08, 1.03-1.14), NO (OR 1.05, 1.02-1.07), $\mathrm{PM}_{2.5}$ (OR 1.03, 1.01-1.05), and $\mathrm{PM}_{10}$ (OR 1.05, 1.02-1.08) (111) Living within 50-200 m of major road associated with increased risk of eczema, allergic rhinitis, atopy and asthma (109)

Pre- or postnatal maternal smoking increased risk of incident wheezing (OR 1.70, $1.24-2.35$ ) and incident asthma (OR 1.85, 1.35-2.53) in children $\leq 2$ years (158)

Secondhand smoke in infancy without prior exposure in utero increased risk of food sensitization (OR 1.47, 1.08-2.00); risk of eczema with sensitization (OR 1.62, 1.20-2.18) (45)

${ }^{A}$ Odds ratios and risk ratios are reported as (OR, 95\% confidence interval) and (RR, 95\% confidence interval). BC, black carbon; HRV, human rhinovirus; NHANES, US National Health and Nutrition Examination Survey; $\mathrm{NO}_{2}$, nitrogen dioxide; $\mathrm{PM}_{2.5}$, particulate matter $2.5 \mu \mathrm{g} / \mathrm{m}^{3} ; \mathrm{PM}_{10}$, particulate matter $10 \mu \mathrm{g} / \mathrm{m}^{3}$; RSV, respiratory syncytial virus; TRAP, traffic-related air pollution.

to our evolution $(18,19)$. Reduced environmental microbial exposures and reduced microbiome diversity may influence host allergic responses by affecting epithelial and immune cells $(1,18,20)$.

The outdoor microbial environment. Environmental exposure to diverse microorganisms has repeatedly demonstrated an inverse association with the manifestation of atopic allergic diseases (6, 18, 20-22). European children from the PARSIFAL and GABRIELA studies raised on rural farms had lower prevalence of atopy and asthma and increased microbial exposure than unexposed children in nonrural environments (Table 1 and refs. 21, 23). Studies comparing populations from wealthier, more Westernized Finland versus more rural Russian Karelia have demonstrated significantly greater allergic disease prevalence in Finland and corresponding differences in skin and nasal microbiota despite similar ancestry and geographic location $(24,25)$. Rural children in China exposed to farming and higher endotoxin levels had decreased asthma risk compared with urban children (26). Amish children living on small traditional US farms had lower asthma prevalence than Hutterite children living on large modern communal farms ( $5 \%$ vs. $23 \%$, respectively) and bacterial home exposure that differed in both quantity and quality (27). Taken together, these findings support a protective role for early bacterial exposure. A clinical trial is under way to test whether oral bacterial extract (ORBEX) administered to high-risk infants can increase the time to occurrence of the first episode of wheezing-related illness after therapy (https://clinicaltrials.gov/ct2/show/NCT02148796).

The origin and nature of bacterial exposure is critical to altering allergic responses. In mice exposed every other day to either Amish or Hutterite house dust extract while being sensitized and challenged with OVA, only Amish dust-exposed mice showed ablated airway resistance and eosinophilia (27). This was dependent on MyD88 and TRIF, which are downstream of TLR4, a pattern recognition receptor that binds endotoxin and the house dust mite (HDM) allergen Derp2 (Figure 1 and ref. 28). In HDM-exposed mice, TLR4 signaling on airway epithelial cells induces Th2 allergic responses (29), but its contribution to allergic responses is 


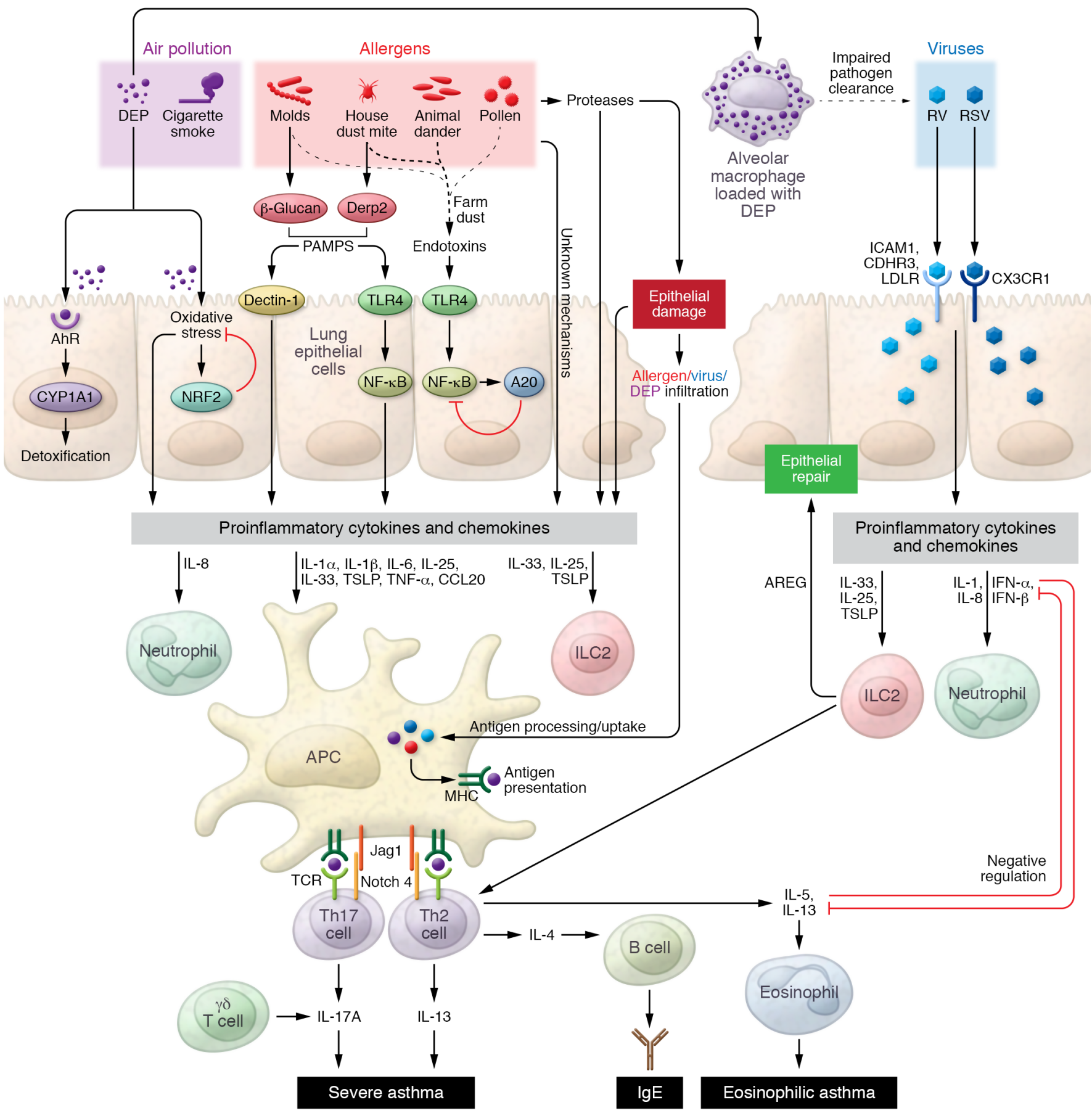

Figure 1. Epithelial pathways impacted by environmental exposures promote asthma pathogenesis. Exposure to air pollutants induces oxidative stress. AhR recognizes polycyclic aromatic hydrocarbons on diesel exhaust particles (DEPs), promoting cytochrome P450 family 1 A1-mediated (CYP1A1-mediated) detoxification. Oxidative stress induces Nrf2 translocation to the nucleus, leading to antioxidant transcription. Failure to detoxify results in release of the neutrophil chemokine IL-8, the antigen-presenting cell (APC) chemokine CCL20, and proinflammatory cytokines (including IL-1, IL-6, and TNF- $\alpha$ ) that in the absence of allergen promote naive T cell differentiation into IL-17A-producing Th17 cells. Similarly, exposure to moldderived $\beta$-glucans, which signal through dectin-1, induces recruitment of IL-17A-secreting Th17 and $\gamma \delta$ T cells and neutrophils. Mold and other complex allergens also stimulate epithelial cells through pathogen-associated molecular pattern (PAMP) receptors like TLRs. TLR4 recognizes the house dust mite allergen Derp2 and endotoxins, which can modulate NF- $\mathrm{BB}$ activation of proinflammatory cytokines via the ubiquitin-modifying enzyme A20. Notch4-Jagged1 interaction between T cells and APCs, respectively, can induce Th2 cell generation when APCs are exposed to allergens and epithelial cell-derived IL-25, IL-33, and/or TSLP. These cytokines can be released following viral infection of epithelial cells and cellular damage resulting from exposure to pollutants and/or proteolytic allergens. They can induce innate lymphoid cells (ILC2s) to release IL-13, which drives mucus production and AHR, and IL-5, which is central to eosinophil biology. In addition to interacting with APCs and Th2 cells to potentiate allergic responses and IgE generation, ILC2s also release amphiregulin (AREG) to promote tissue repair. HRV and RSV infections in asthmatics can exacerbate Th2 responses and inhibit type 1 IFN responses, enhancing viral replication and promoting more severe disease. 


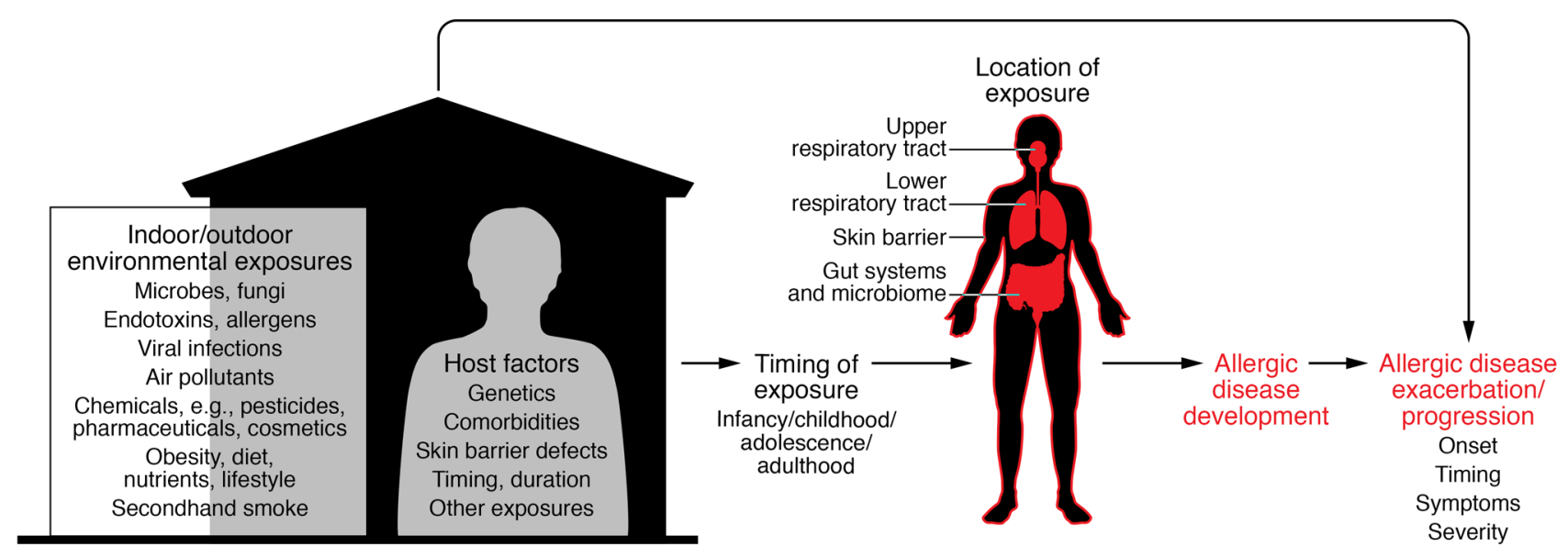

Figure 2. Interplay of indoor and outdoor environmental exposures and host factors that affect lifelong allergic disease development and progression. Allergic disease development is influenced by many environmental exposures that may interact with host factors and trigger a host response. These exposures may be part of the outdoor, indoor, or host environment. The timing of environmental exposures is important in the development and progression of allergic disease. Common factors within the external, internal, and host environments contribute to disease development, exacerbation, and lifelong progression. The host response to different exposures varies depending on host genetics and epigenetics in addition to other host factors that influence the timing and onset of allergic disease symptoms and severity.

likely influenced by load, cell type, and timing of exposure (30). Chronic low-dose LPS or farm dust exposure in mice can prevent development of HDM-induced allergic immune response by a mechanism involving A20, a ubiquitin-modifying enzyme that partially inhibits NF- $\mathrm{\kappa B}$ signaling in lung epithelial cells, supporting a protective role for bacterial exposure (31). It remains to be seen which bacteria confer this protective effect and how these findings may differ in urban areas.

Indoor microbe and allergen exposure. The indoor microbial environment is determined by a dwelling's inhabitants. Dog ownership increases house dust diversity by introducing additional bacterial taxa compared with homes with cats or without pets (32). Exposure to dog and/or cat has been implicated as both a risk and a protective factor for developing allergic symptoms, allergic sensitization, or asthma $(33,34)$. Dog ownership may act as a surrogate marker for particular microbial exposures that enhance the protective effect of pet ownership against allergic disease (32). The protective effect on allergic disease risk may depend on pet exposure during the first year of life, which correlates with the timing of endotoxin exposure that confers the most significant protective effects (Figure 2 and refs. 1, 35, 36). In a Swedish birth cohort, dog exposure during the first year of life conveyed a reduced risk of asthma at age 6 independent of parental asthma (37). The cumulative evidence suggests no increased risk of allergic disease from pet exposure $(1,33,34)$. However, the Institute of Medicine recently found sufficient evidence of association between dog and cat allergen exposure and asthma exacerbation, but only in individuals sensitized to those particular allergens (2). Increased levels of IgE to furry-animal allergens are associated with allergy-related symptoms, but polysensitization (IgE-specific for three or more cat or dog allergens) during early childhood may predict cat and dog allergy better than IgE to cat or dog extract (38). In the United States, where pet ownership is common $(36.5 \%$ of households own a dog and $30.4 \%$ a cat), an estimated excess of $1,700,000$ asthma attacks and 700,000 asthma emergency care visits each year are associated with elevated levels of pet allergen in bedrooms of sensitized patients (39).

Indoor fungal exposure and asthma. Indoor fungal exposure, defined by the presence of visible fungi/mold, visible dampness, and/or mold odor, is present in $18 \%$ to $50 \%$ of household dwellings worldwide (40-43). Old houses ( $\geq 90$ years) and those with damp indoor environments are at increased risk of higher concentrations of Penicillium and Aspergillus species $(43,44)$. Indoor fungal profiles vary by geographic location, season, air exchange rates, and interaction with outdoor sources of fungi, such as Cladosporium and Alternaria species (43). The Institute of Medicine found sufficient evidence of a causal association between dampness or dampness-related agents and asthma exacerbation in children (2). Numerous epidemiologic studies have determined indoor fungal exposure to be associated with asthma, wheeze, allergic rhinitis, and eczema in both atopic and nonatopic individuals $(41,42,44$, 45). Fungal exposure has consistently been associated with the highest excess risk for development and exacerbation of asthma $(43,44)$ and rhinitis $(45,46)$. Exposure to an increased number of mold or dampness indicators in infancy has been associated with a greater risk of allergic (47) and nonallergic asthma $(44,45)$. However, there is evidence that mold exposure can be protective. Exposure to higher fungal diversity shortly after birth has been associated with decreased risk of wheezing and aeroallergen sensitization later in childhood $(48,49)$ similar to the aforementioned protective role of endotoxins.

Environmental fungal exposure promotes allergic disease through immune responses to both fungal-specific pathogen-associated molecular patterns (PAMPs) and proteolytic allergens (50). Fungal spores and conidia are protected by a rigid outer wall of $\beta$-glucans with an outer mannan layer and an inner chitin layer that enables signaling through C-type lectin receptors (ref. 51 and Figure 1). The immune system recognizes $\beta$-glucans using the dectin-1 receptor, while mannans bind a range of C-type lectins 
$(50,51)$. In mice, fungal-derived chitin exposure induced IL-25, IL-33, and thymic stromal lymphopoietin (TSLP), activated type 2 innate lymphoid cells (ILC2s), and drove Th2 allergic inflammation, whereas inhibition of this pathway increased activation of IL-17A-producing $\gamma \delta$ T cells and prolonged neutrophilia $(52,53)$. In a mouse asthma model, exposure to HDM allergen and curdlan, a linear $\beta$-glucan that induces a robust IL-17A response, enhanced airway hyperresponsiveness (AHR) and airway inflammation in the absence of fungal sensitization, demonstrating that the impact of fungal exposure may be more dependent on the direct immunomodulatory functions of fungal components rather than its ability to act as a sensitizing agent (54).

Mold species are capable of inducing distinct inflammatory lung phenotypes based on the mold's available surface PAMPs. Cladosporium cladosporioides has high $\beta$-glucan content, but limited surface availability (55); Aspergillus versicolor has lower $\beta$-glucan content, but higher surface availability of $\beta$-glucans. In mice, inhalation of $C$. cladosporioides spores induced robust AHR and eosinophilia, whereas A. versicolor induced a strong dectin-1mediated Th17 response and neutrophilic inflammation, but mild AHR (55). Mice exposed to heat-killed C. cladosporioides spores with more exposed $\beta$-glucans on their surface exhibited dectin-1-mediated Th17 and neutrophilic inflammation (56). In the absence of dectin-1, heat-killed spores induced a predominantly Th2 response similar to that induced by live spores, indicating that the immune response is dependent on surface availability of $\beta$-glucans (56). In mice, $\beta$-glucans also exacerbated allergen-induced allergic responses in a dectin-1-dependent manner (54, 57). These findings highlight several innate pathways triggered by mold exposure and resulting in a mixed Th2/Th17 response associated with more severe asthma.

Airway smooth muscle cells can respond directly to inhaled fungi to generate AHR. A major allergen of Aspergillus fumigatus (Asp f13) is a serine protease (alkaline protease 1; Alp1) that has been detected in the lungs of severe asthmatics and inversely correlated with forced expiratory volume in one second (FEV1) (58). Alp1 promotes calcium flux and contraction of smooth muscle cells (58). Mice repeatedly exposed to Aspergillus lacking Asp f13 had significantly lower pulmonary inflammation and signs of remodeling, supporting a role for the endogenous protease activity; however, AHR was unchanged, demonstrating the complexity of fungal actions (59). Fungal proteases can also cleave protease-activated receptor-2 (PAR2), triggering innate immune responses. Following Alternaria alternata exposure, PAR2-mediated serine protease-induced activation has been shown to induce the release of IL-33 from human bronchial epithelial cells (60). Similarly, in mice, Alternaria exposure induced IL-33, Th2 cytokines, IgE, and AHR $(61,62)$. These Th2 responses were attenuated in ST2-deficient mice lacking a functional IL-33 receptor, suggesting a role for IL-33 in severe asthma with fungal sensitization (62). However, the mechanisms by which fungal exposure contributes to allergic disease are not fully delineated.

Viral infections in wheezing and asthma development. Early-life acute respiratory tract infections (ARIs) are strongly associated with wheeze in infants and asthma inception and exacerbation in children; however, it is still debated whether they are causative in the pathogenesis of asthma or whether they unmask asthma susceptibility (63-65). ARIs caused by human rhinovirus (HRV), respiratory syncytial virus (RSV), parainfluenza viruses, and other pathogens are common in early childhood (10\%-30\% bronchiolitis prevalence in the first 2 years) (64). ARIs provoke wheezing in individuals with and without asthma. Up to $50 \%$ of children will have acute ARI-associated wheezing before school age, and 30\% to $40 \%$ of these will have recurrent wheeze (66).

HRV-associated bronchiolitis and wheezing illnesses are a more robust marker of asthma risk than those caused by RSV or other viruses $(66,67)$. Upon infection with HRV, patients with asthma have more severe airway symptoms than nonasthmatic controls (68). HRVs are single positive-stranded RNA enteroviruses classified into three species (HRV-A, HRV-B, and HRV-C) and over 160 distinct genotypes (67). HRVs utilize three major types of cellular membrane glycoproteins to enter respiratory epithelial cells: intercellular adhesion molecule 1 (ICAM-1) (HRV-A and HRV-B), low-density lipoprotein receptor (LDLR) family members (HRV-A), and cadherin-related family member 3 (CDHR3) (HRV-C) (67). HRV-associated wheezing in the first 3 years of life doubled the risk of subsequent asthma development (69). Among neonates with high familial risk for asthma, having at least one HRV-associated wheezing episode during the first 3 years of life increased the likelihood of wheezing in the third year (OR 10.0) more than having at least one RSV-associated wheezing episode (OR 3.0) (70). Prospective studies have shown that RSV-induced bronchiolitis is associated with subsequent asthma development $(67,71,72)$ and with recurrent wheeze $(63,73)$, but this may reflect an underlying predisposition to asthma and not a causal mechanism.

The interaction between early-life ARI and allergic sensitization increases the risk of subsequent asthma $(63,66)$. Children followed prospectively from birth to age 13 years with HRV-induced wheeze and aeroallergen sensitization by age 3 years had the highest incidence of subsequent asthma development compared with sensitization or HRV-wheezing alone (74). Among children in the Cincinnati Childhood Allergy and Air Pollution Study (CCAAPS), having at least 6 ARIs in the first year of life and early sensitization to mold increased asthma risk at age 7 years 12 -fold compared with children with fewer than 6 ARIs who were not sensitized (75). This suggests that the load and timing of viral exposure may be important in progression to asthma. The strength of association between early-life ARI and childhood asthma is large in comparison with other environmental risk factors, but determining causality in children is not possible for ethical reasons (76). However, Beigelman et al. suggest that at least seven of nine Hill's criteria for causality are met for respiratory viruses (76). Evidence from a randomized, double-blind, placebo-controlled trial showing significant reductions in recurrent wheeze among healthy preterm infants who received palivizumab to prevent RSV infections supports the concept of a causal relationship $(76,77)$.

Mechanisms of viral-induced wheezing. Transcriptomic analysis comparing asthmatics with nonasthmatic controls following infection with HRV demonstrated increased magnitude and persistence of epithelial gene dysregulation throughout the course of infection (78). Distinct differences in the quality of the response following HRV infection were observed in asthmatics, including increased expression of genes involved in inflammation, decreased expression of viral replication inhibitors, and impaired induction of the 
serine protease inhibitor SPINK5, which has been implicated in epithelial maintenance and repair (78). Patients with asthma also displayed increased upper and lower respiratory symptoms, markedly higher viral load, and higher nasal Th2 cytokine levels (68). Accordingly, supernatants from HRV-infected primary bronchial epithelial cells induced IL- 5 and IL-13 production from isolated CRTH2 ${ }^{+}$ILC2s and promoted Th2 differentiation in vitro in an IL-33-dependent manner, suggesting a link between infection and asthma exacerbation (68). In a sister study, bronchial epithelial cells from asthmatic individuals released significantly more IL-25 upon infection with HRV-1B than control cells (79). In neonatal mice, HRV infection increased IL-25, IL-33, and TSLP expression (80), and neutralizing antibody against IL-25 abolished ILC2 expansion, mucous metaplasia, and AHR in HRV-infected neonatal mice (81). These findings suggest that early-life viral infection may contribute to asthma development and exacerbation by provoking type 2 immune responses.

In humans, these viral-induced type 2 innate responses likely favor allergic Th2 responses upon exposure to common aeroallergens. This type 2 environment has been shown to inhibit type 1 interferon antiviral responses in infected cells from asthmatic patients, further exacerbating disease $(65,82-84)$. RSV-infected human neonatal regulatory B cells upregulated CX3CR1 to promote infection and release of IL-10 that inhibited antiviral responses and exacerbated disease in a manner favoring microbial pathogenesis (85). In mice, pathogenic clinical isolates of RSV induced accumulation of ILC2s via a TSLP-dependent mechanism (86) and increased susceptibility to atopic asthma through impairment of regulatory $\mathrm{T}$ cells and promotion of a Th2 response (87). Thus, impaired antiviral responses in early life result in increased disease and the development of asthma $(65,67,88,89)$. Treatment strategies limiting type 2 responses may alleviate viral-induced asthma exacerbations partly by restoring antiviral responses (65).

A missense variant in CDHR3 (receptor for HRV-C) has also been associated with childhood asthma exacerbations (90). Overall, this evidence highlights the complex interplay of environmental microbial exposures and host factors that influence the timing and the development of allergic disease.

\section{Impact of air pollution on allergic disease}

Air pollutants can cause adverse health effects worldwide (14, 9194). Outdoor air pollution frequently occurs as a mixture of natural pollutants (e.g., from wildfires, volcanoes, biological decay, dust storms) and human-made pollutants (e.g., from motor vehicles, biomass burning, power plants, industrial facilities, waste incinerators, pesticides) (Figure 2 and refs. 9, 91, 95). Sulfur dioxide, nitrogen oxides $\left(\mathrm{NO}_{\mathrm{x}}\right)$, carbon monoxide $(\mathrm{CO})$, and particulate matter (PM) are typical outdoor air pollutants from fuel combustion or motor vehicle emissions.

Concern is increasing over indoor air pollution since some societies spend up to $90 \%$ of time inside exposed to pollutants from tobacco smoke, solid fuels, stoves, construction materials, ambient PM, and biological materials (mold spores, viruses and bacteria, animal dander, and HDMs) $(91,96)$. Indoor air pollution is determined partly by outdoor air quality depending on ventilation systems and cleaning practices. Additional environmental chemical exposures associated with atopic disease include phar- maceuticals, cosmetic products, flame retardants, and others (97100). Volatile organic compounds (VOCs) are also worrisome as Westernized societal exposure shifts from transport-related VOCs to VOCs from coatings, adhesives, and consumer products that alter urban air quality (101). Additionally, VOCs react with $\mathrm{NO}_{2}$ in the presence of sunlight to form ozone. Overall, the risk of air pollution is a function of the hazard of the pollutant, the combination of pollutants and their interactions, and the extent of exposure (96). Here, we focus on the impact of traffic-related air pollution (TRAP) and tobacco smoke in allergic disease and asthma.

TRAP exposures. An expert panel for the Health Effects Institute found sufficient evidence that exposure to TRAP causes asthma exacerbation in children (102). TRAP produced by motor vehicles is made up of a complex mixture of PM, reported as black carbon (BC), $\mathrm{PM}_{10}$, and/or $\mathrm{PM}_{2.5}$; and gaseous emissions including $\mathrm{NO}_{\mathrm{x}}, \mathrm{CO}$, ozone, and other air pollutants $(9,91,103)$. Diesel exhaust particles (DEPs) are of particular concern and contributed to more than $90 \%$ of the PM derived from traffic sources in European and American cities (103). This exposure is significant in cities where up to $45 \%$ of the population resides in zones most impacted by TRAP $(102,104,105)$. Despite falling sales, diesel-powered cars still represent a major portion of cars on the road in Europe and India. Air quality and engine exhaust control policies implemented in 2005 to 2010 have not produced rapid changes in TRAP levels (106).

Evidence suggests that TRAP is associated with reduced lung growth, lower lung function, and development and exacerbation of asthma (107-110). Meta-analyses estimated significantly increased risk estimates for $\mathrm{BC}, \mathrm{NO}_{2}, \mathrm{PM}_{2.5}$, and $\mathrm{PM}_{10}$ exposures and subsequent development of childhood asthma (Table 1 and ref. 111). Near-roadway exposure is associated with increased asthma prevalence, chronic lower respiratory symptoms, phlegm production, bronchitis, wheeze, and medication use (112), and decreased lung function, lifetime diagnoses and symptoms of allergic rhinitis, and allergic sensitization among school-aged children (113). Exposure to pollutants from roads with high vehicle traffic contributed to an estimated $14 \%$ of incident childhood asthma and $15 \%$ of childhood asthma exacerbation (104). In CCAAPS, a child's risk for persistent wheeze and asthma development varied depending on the timing, duration, and level of TRAP exposure (114-117). Accordingly, meta-analysis data suggest that TRAP exposure may have ongoing effects with a 3-year lag time (108). TRAP exposure in infancy resulted in a $40 \%$ to $83 \%$ increased risk of aeroallergen sensitization by age $4(118,119)$ and increased risk of food allergy by age 8 years (118). TRAP and other air pollutants also act as risk factors for eczema development and/or aggravation of eczema symptoms (91).

Collectively, there is mounting evidence supporting the contribution of TRAP to allergic diseases, although some meta-analyses have reported conflicting associations $(108,120)$. Meta-analyses of American and European cohorts observed substantial heterogeneity across studies that limited the ability to draw conclusions related to diverse definitions in exposure (land-use regression/ dispersion models and roadway proximity) and outcomes (asthma, wheeze, allergic sensitization), and unmeasured confounding of other factors (environmental pollens, fungal spores, climate; socioeconomic) and their complex interactions that drive allergic disease and modify the effects of TRAP exposure $(103,108)$. 
Several mechanisms contribute to TRAP-induced allergic disease development and exacerbation, including oxidative stress, altered barrier integrity, and induction of inflammation (14, 95, 121). Interpretations from mouse studies of TRAP depend on the nature of the traffic pollutant studied. DEPs are coated with heavy metals and organic compounds (e.g., polycyclic aromatic hydrocarbons), but can also carry pollen and airborne PAMPs depending on the local environment (122). Thus, DEPs collected from diesel engine vehicle exhaust will not necessarily recapitulate immune responses to ambient PM collected in urban cities (123). Nevertheless, inhaled ambient PM (and DEPs) adversely affects the bronchial epithelium by promoting oxidative stress, which has been implicated in key pathophysiological features of asthma (124). Briefly, exposure to DEPs induces a cascade of events including translocation of the transcription factor NF-E2-related factor 2 (Nrf2) to the nucleus and induction of antioxidants (e.g., heme oxygenase-1) to detoxify the cell and limit oxidative injury (Figure 1 and refs. 125, 126). PM exposure has also been shown to disrupt epithelial tight junctions in a dose-dependent manner, and alleviating oxidative stress restored normal epithelial barrier function (127-129). Thus, PM-induced oxidative stress could damage the integrity of epithelial barriers, allowing aeroallergens to gain entry into pulmonary tissues, facilitating uptake by antigen-presenting cells (APCs), and promoting allergic sensitization. Numerous studies have demonstrated increased allergen-specific IgE levels following coexposure to allergen and DEPs $(108,118,119,130)$.

Particulate matter-induced inflammation. The nature of PM-induced inflammation is context dependent. In cultured human epithelial cells, DEP exposure leads to NF- $\mathrm{BB}$ activation and transcription of proinflammatory cytokines (IL- $1 \beta$, IL-6, TNF- $\alpha$ ) and neutrophil chemokines such as IL-8 $(121,128)$. Accordingly, acute exposure to DEPs generated an inflammatory response dominated by neutrophils in healthy adults but no changes in lung function $(131,132)$. In contrast, decreased lung function has been shown in DEP-exposed asthmatics (133). Primary bronchial epithelial cells obtained from asthmatic patients and exposed to DEPs have increased mRNA and protein levels of IL-25, IL-33, and TSLP, and this induction is dependent on the aryl hydrocarbon receptor (AhR) (134). These epithelial-derived cytokines promote dendritic cell maturation and shape APC responses to allergen exposures $(135,136)$.

In $\mathrm{T}$ cells, Notch signaling is essential for allergic inflammation (137). Exposure to fine particles and ultrafine particles (UFPs; $<0.2 \mu \mathrm{m}$ ) upregulated Jagged-1 (Jag1), the Notch signaling ligand on APCs (138). In mice, exposure to UFPs enhanced allergen-induced AHR, IgE production, and Th2/Th17 inflammation resulting from AhR-dependent induction of Jag1 expression in alveolar macrophages (AMs) (138). AMs are the major pulmonary cell type involved in phagocytosis of UFPs. Jag1-expressing AMs interacted with Notch4-bearing naive allergen-specific T cells to promote Th2 and Th17 differentiation (138), albeit only in AMs harboring a constitutively active IL-4 receptor $(138,139)$. This is consistent with a more severe asthma phenotype observed in patients with this IL4RA ${ }^{\mathrm{R} 576}$ polymorphism $(139,140)$.

DEP exposure is associated with increased IL-17A levels in human and murine asthma (141). In mice, IL-17A blockade prevented DEP-induced exacerbation of allergic asthma (141). This increase in DEP-mediated disease severity is associated with an impaired response to steroid treatment and increased IL-17A (141, 142), which can directly induce smooth muscle contraction (143). In mice, coexposure to HDMs and DEPs induced pulmonary accumulation of T cells that coproduce Th2 and Th17 cytokines (130, 141). In asthmatic patients, the presence of these dual Th2/Th17 cells, which are more resistant to steroids in vitro, is associated with more severe disease (144). After transfer into naive mice, Th2/Th17 cells have been shown to promote more severe disease than classic Th2 cells (145). Additionally, simultaneous exposures to IL-13 and IL-17A can exacerbate IL-13-induced AHR by enhancing IL-13/STAT6 signaling (146), which suggests that cells cosecreting IL-13 and IL-17A would be ideally poised to generate a stronger STAT6 response in epithelial and smooth muscle cells, a pathway critically involved in allergic AHR (147). DEP exposure promoted increased numbers and persistence of allergen-specific memory T cells in adult and neonatal murine lungs (130). Accordingly, coexposure to high TRAP in the first year of life was associated with earlier allergen sensitization and increased prevalence of asthma at age 7 in allergen-sensitized children (130).

TRAP exposure may alter the immune system even before birth. DEPs can cross the placenta and induce oxidative stress pathways in the fetus; thus maternal exposure has the potential for negative health effects to the fetus (148). Offspring of female mice exposed to DEPs in utero and sensitized to OVA postnatally were primed for enhanced allergen-induced bronchoalveolar lavage fluid inflammation, increased Th2 and Th17 cytokines, and elevated AHR compared with unexposed offspring (149-151). The associated increase in lung levels of genes induced by direct DEP exposures suggests that some DEPs likely crossed the placental barrier and resulted in a primed state and asthma susceptibility in offspring.

Tobacco smoke exposures. In 2015, one-quarter of men and 5.4\% of women worldwide smoked daily (152), exposing up to $40 \%$ of nonsmokers to secondhand smoke (SHS) (153). An estimated 36,950 asthma deaths in adults and children were attributable to SHS exposure in 2004 according to comprehensive disease data from WHO (153). SHS exposure is also a risk factor for allergic sensitization, allergic rhinitis, and allergic dermatitis among children (154-156). Further, smoking among asthmatics promotes emphysema and decline in lung function, resulting in chronic obstructive pulmonary disease over time.

There is convincing evidence suggesting a causal relationship between SHS exposure and asthma incidence in children (2, 153, 157-159). Prenatal or postnatal maternal smoking was associated with significantly increased risks of incident wheezing (28\%-70\%) and incident asthma (20\%-85\%) up to age 18 years (158). Even in the absence of maternal smoking, SHS exposure in infancy increased the risk of food sensitization and the risk of eczema with allergic sensitization up to age 16 years $(156,160)$. In the Greater Cincinnati Pediatric Clinic Repository cohort, 33\% of the asthmatic children aged 5 to 18 years lived with a smoker; of these, $66 \%$ of mothers reported smoking in the household (3). Children in lower-income families were almost 3 times more likely to be exposed to SHS than those in higher-income families (161). Strong evidence of an SHS exposure-response relationship and induction of asthma in children, adolescents, and adults makes prevention efforts critical (162-165). Further, thirdhand smoke (THS; residual smoke contamination remaining after the source 
of tobacco smoke has been extinguished) can accumulate on surfaces, becoming progressively more toxic, and can contribute to overall tobacco smoke exposure (166-168). New research demonstrated that components of THS can exacerbate a mouse asthma model through mast cells, resulting in airway inflammation and remodeling (168).

E-cigarette use has substantially increased over the past 5 years worldwide (169-171). Levels of toxicants in e-cigarette vapor are lower than those in smoke from combustible cigarettes (172), but safety data regarding their usage are limited. Evidence indicates that e-cigarette vapor can produce oxidative stress and inflammation in airways and may exacerbate or induce rhinitis, asthma, eczema, and allergic symptoms (173). Epidemiologic investigations found increased e-cigarette use among asthmatics $(174,175)$ and associations between e-cigarette use and increased asthma (176) and asthma attack (175) prevalence. Exposure to nicotine-containing e-liquid in "asthmatic" mice increased airway eosinophils, Th2 cytokines, and $\operatorname{AHR}(172,177)$. The toxicity of components unique to e-cigarettes likely induces unique respiratory and possibly allergic effects and warrants further investigation $(172,174)$.

Exposure to cigarette smoke alters immune mechanisms involved in allergic disease. As with traffic-related diesel pollution, AMs from smokers displayed reduced phagocytic abilities impairing both pathogen clearance from the lungs and removal of dead cells $(178,179)$. Exposure to cigarette smoke increased production of IFN- $\gamma$ and IL-17A by T cells in murine lungs, and recruitment of AMs, neutrophils, and $\gamma \delta$ T cells, a major source of IL-17A (180). Smoke-exposed $\gamma \delta \mathrm{T}$ cell-deficient mice failed to mount an effective immune response to influenza A (181). Cigarette smoke also induced oxidative stress, which can increase TSLP and IL-33 expression in the lungs (182-184). Smoke exposure induced IL-33 accumulation in epithelial cells, but viral infection or proteolytic allergen exposure is likely needed to release and activate IL-33 $(183,185)$.

Offspring from mice that are coexposed to allergen and tobacco smoke have increased asthma susceptibility $(186,187)$. Accordingly, nasopharyngeal aspirates from SHS-exposed asthmatic children revealed higher concentrations of IL-13 compared with SHS-unexposed asthmatic and control subjects (188). In utero exposure to cigarette smoke also affected lung development in murine offspring, and this negative impact extended to the next generation, suggesting epigenetic changes $(187,189)$. This is supported by recent findings demonstrating durable methylation changes in mice exposed to tobacco smoke in utero (190). Further research is needed to understand how interactions between smoke, viral, and allergen exposures in early life impact allergic disease development.

\section{Conclusion}

The effects of environmental exposures early in life contribute to the development of allergic disease and asthma later in life. The influence of these environmental factors on allergic mechanisms likely differs based on host genetics, host immunologic milieu, timing, and other exposures. The inconsistencies in current research regarding the relationship between the environment and atopy reflect these complexities and the need for improved exposure assessment and rigorous study design $(1,2)$. A comprehensive and integrated approach to allergic diseases that remain a significant public health problem, especially among children, will (a) establish basic molecular profiles to develop novel molecular insights into disease etiology and clinical severity, (b) produce environmental and biological signatures to create a roadmap for primary and secondary prevention of allergic disease, and (c) provide the rationale and targets for disease intervention (191). An improved understanding of the complex interactions between modifiable environmental factors and the dynamic biological processes that govern allergic mechanisms will advance our ability to prevent allergic diseases.

\section{Acknowledgments}

Funding support was provided by NIH grant U19AI070235.

Address correspondence to: Gurjit K. Khurana Hershey, Division of Asthma Research, Cincinnati Children's Medical Center, 3333 Burnet Avenue, MLC 7037, Cincinnati, Ohio 45229, USA. Phone: 513.636.7054; Email: Gurjit.Hershey@cchmc.org.
1. Burbank AJ, Sood AK, Kesic MJ, Peden DB, Hernandez ML. Environmental determinants of allergy and asthma in early life. JAllergy Clin Immunol. 2017;140(1):1-12.

2. Kanchongkittiphon W, Mendell MJ, Gaffin JM, Wang G, Phipatanakul W. Indoor environmental exposures and exacerbation of asthma: an update to the 2000 review by the Institute of Medicine. Environ Health Perspect. 2015;123(1):6-20.

3. Butsch Kovacic M, et al. The Greater Cincinnati Pediatric Clinic Repository: a novel framework for childhood asthma and allergy research. Pediatr Allergy Immunol Pulmonol. 2012;25(2):104-113.

4. Kay AB. Allergy and allergic diseases. First of two parts. NEngl JMed. 2001;344(1):30-37.

5. Bantz SK, Zhu Z, Zheng T. The atopic march: progression from atopic dermatitis to allergic rhinitis and asthma. J Clin Cell Immunol. 2014;5(2):202.

6. Platts-Mills TA. The allergy epidemics: $1870-$ 2010. J Allergy Clin Immunol. 2015;136(1):3-13.

7. Mallol J, et al. The International Study of Asthma and Allergies in Childhood (ISAAC) Phase Three: a global synthesis. Allergol Immunopathol (Madr). 2013;41(2):73-85.

8. Pearce $\mathrm{N}$, et al. Worldwide trends in the prevalence of asthma symptoms: phase III of the International Study of Asthma and Allergies in Childhood (ISAAC). Thorax. 2007;62(9):758-766.

9. Guarnieri M, Balmes JR. Outdoor air pollution and asthma. Lancet. 2014;383(9928):1581-1592.

10. Rodriguez A, et al. Urbanisation is associated with prevalence of childhood asthma in diverse, small rural communities in Ecuador. Thorax. 2011;66(12):1043-1050.

11. Morgan BW, et al. Asthma and allergic disorders in uganda: a population-based study across urban and rural settings. J Allergy Clin Immunol Pract. 2018;6(5):1580-1587.e2.

12. Han H, Roan F, Ziegler SF. The atopic march: current insights into skin barrier dysfunction and epithelial cell-derived cytokines. Immunol Rev. 2017;278(1):116-130.

13. Johansson E, Hershey GKK. Contribution of an impaired epithelial barrier to the atopic march. Ann
Allergy Asthma Immunol. 2018;120(2):118-119.

14. Ngoc LTN, Park D, Lee Y, Lee YC. Systematic review and meta-analysis of human skin diseases due to particulate matter. Int J Environ Res Public Health. 2017;14(12):E1458.

15. Kim K. Influences of environmental chemicals on atopic dermatitis. Toxicol Res. 2015;31(2):89-96.

16. Boguniewicz M, Leung DY. Atopic dermatitis: a disease of altered skin barrier and immune dysregulation. Immunol Rev. 2011;242(1):233-246.

17. Strachan DP. Hay fever, hygiene, and household size. BMJ.1989;299(6710):1259-1260.

18. Lambrecht BN, Hammad H. The immunology of the allergy epidemic and the hygiene hypothesis. Nat Immunol. 2017;18(10):1076-1083.

19. Rook GA. Hygiene hypothesis and autoimmune diseases. Clin Rev Allergy Immunol. 2012;42(1):5-15.

20. Liu AH. Revisiting the hygiene hypothesis for allergy and asthma. J Allergy Clin Immunol. 2015;136(4):860-865.

21. Ege MJ, et al. Exposure to environmental microorganisms and childhood asthma. N Engl JMed. 
2011;364(8):701-709.

22. Ege MJ, et al. Gene-environment interaction for childhood asthma and exposure to farming in Central Europe. J Allergy Clin Immunol. 2011;127(1):138-144.e1.

23. Birzele LT, et al. Environmental and mucosal microbiota and their role in childhood asthma. Allergy. 2017;72(1):109-119.

24. Ruokolainen L, et al. Significant disparities in allergy prevalence and microbiota between the young people in Finnish and Russian Karelia. Clin Exp Allergy. 2017;47(5):665-674.

25. Laatikainen T, et al. Allergy gap between Finnish and Russian Karelia on increase. Allergy. 2011;66(7):886-892.

26. Feng M, et al. Associations of early life exposures and environmental factors with asthma among children in rural and urban areas of Guangdong, China. Chest. 2016;149(4):1030-1041.

27. Stein MM, et al. Innate immunity and asthma risk in Amish and Hutterite farm children. $N$ Engl J Med. 2016;375(5):411-421.

28. Trompette A, et al. Allergenicity resulting from functional mimicry of a Toll-like receptor complex protein. Nature. 2009;457(7229):585-588.

29. Hammad H, Chieppa M, Perros F, Willart MA, Germain RN, Lambrecht BN. House dust mite allergen induces asthma via Toll-like receptor 4 triggering of airway structural cells. Nat Med. 2009;15(4):410-416.

30. Zakeri A, Russo M. Dual role of toll-like receptors in human and experimental asthma models. Front Immunol. 2018;9:1027.

31. Schuijs MJ, et al. Farm dust and endotoxin protect against allergy through A20 induction in lung epithelial cells. Science. 2015;349(6252):1106-1110.

32. Fujimura KE, et al. Man's best friend? The effect of pet ownership on house dust microbial communities. JAllergy Clin Immunol. 2010;126(2):410-412.e1.

33. Takkouche B, González-Barcala FJ, Etminan M, Fitzgerald M. Exposure to furry pets and the risk of asthma and allergic rhinitis: a meta-analysis. Allergy. 2008;63(7):857-864.

34. Lødrup Carlsen KC, et al. Does pet ownership in infancy lead to asthma or allergy at school age? Pooled analysis of individual participant data from 11 European birth cohorts. PLoS One. 2012;7(8):e43214.

35. Ownby DR, Johnson CC. Dogs, cats, and asthma: will we ever really know the true risks and benefits? JAllergy Clin Immunol. 2016;138(6):1591-1592.

36. Chen CM, Tischer C, Schnappinger M, Heinrich $\mathrm{J}$. The role of cats and dogs in asthma and allergy - a systematic review. Int J Hyg Environ Health. 2010;213(1):1-31.

37. Fall $\mathrm{T}$, et al. Early exposure to dogs and farm animals and the risk of childhood asthma. JAMA Pediatr. 2015;169(11):e153219.

38. Asarnoj A, et al. Sensitization to cat and dog allergen molecules in childhood and prediction of symptoms of cat and dog allergy in adolescence: a BAMSE/MeDALL study. J Allergy Clin Immunol. 2016;137(3):813-821.e7.

39. Gergen PJ, et al. Sensitization and exposure to pets: the effect on asthma morbidity in the US population. J Allergy Clin Immunol Pract. 2018;6(1):101-107.e2.
40. Mudarri D, Fisk WJ. Public health and economic impact of dampness and mold. Indoor Air. 2007;17(3):226-235.

41. [No authors listed]. WHO Guidelines for Indoor Air Quality: Dampness and Mould. Geneva, Switzerland:World Health Organization; 2009. https:// www.ncbi.nlm.nih.gov/books/NBK143941/.

42. Mendell MJ, Mirer AG, Cheung K, Tong M, Douwes J. Respiratory and allergic health effects of dampness, mold, and dampness-related agents: a review of the epidemiologic evidence. Environ Health Perspect. 2011;119(6):748-756.

43. Sharpe RA, Bearman N, Thornton CR, Husk K, Osborne NJ. Indoor fungal diversity and asthma: a meta-analysis and systematic review of risk factors. J Allergy Clin Immunol. 2015;135(1):110-122.

44. Tischer CG, et al. Meta-analysis of mould and dampness exposure on asthma and allergy in eight European birth cohorts: an ENRIECO initiative. Allergy. 2011;66(12):1570-1579.

45. Thacher JD, et al. Mold and dampness exposure and allergic outcomes from birth to adolescence: data from the BAMSE cohort. Allergy. 2017;72(6):967-974.

46. Jaakkola MS, Quansah R, Hugg TT, Heikkinen SA, Jaakkola JJ. Association of indoor dampness and molds with rhinitis risk: a systematic review and meta-analysis. J Allergy Clin Immunol. 2013;132(5):1099-1110.e18.

47. Reponen T, et al. High environmental relative moldiness index during infancy as a predictor of asthma at 7 years of age. Ann Allergy Asthma Immunol. 2011;107(2):120-126.

48. Douwes J, et al. Does early indoor microbial exposure reduce the risk of asthma? The Prevention and Incidence of Asthma and Mite Allergy birth cohort study. J Allergy Clin Immunol. 2006;117(5):1067-1073.

49. Iossifova YY, et al. Mold exposure during infancy as a predictor of potential asthma development. Ann Allergy Asthma Immunol. 2009;102(2):131-137.

50. Bartemes KR, Kita H. Innate and adaptive immune responses to fungi in the airway. J Allergy Clin Immunol. 2018;142(2):353-363.

51. Hadebe S, Brombacher F, Brown GD. C-Type lectin receptors in asthma. Front Immunol. 2018;9:733.

52. Van Dyken SJ, Locksley RM. Chitins and chitinase activity in airway diseases. J Allergy Clin Immunol. 2018;142(2):364-369.

53. Van Dyken SJ, et al. Chitin activates parallel immune modules that direct distinct inflammatory responses via innate lymphoid type 2 and $\gamma \delta$ T cells. Immunity. 2014;40(3):414-424.

54 . Zhang $Z$, et al. $\beta$-Glucan exacerbates allergic asthma independent of fungal sensitization and promotes steroid-resistant TH2/TH17 responses. J Allergy Clin Immunol. 2017;139(1):54-65.e8.

55. Mintz-Cole RA, Gibson AM, Bass SA, Budelsky AL, Reponen T, Hershey GK. Dectin-1 and IL-17A suppress murine asthma induced by Aspergillus versicolor but not Cladosporium cladosporioides due to differences in $\beta$-glucan surface exposure. $J$ Immunol. 2012;189(7):3609-3617.

56. Mintz-Cole RA, Brandt EB, Bass SA, Gibson AM, Reponen T, Khurana Hershey GK. Surface availability of beta-glucans is critical determinant of host immune response to Cladospo- rium cladosporioides. J Allergy Clin Immunol. 2013;132(1):159-169.

57 . Hadebe $S$, et al. $\beta$-Glucan exacerbates allergic airway responses to house dust mite allergen. Respir Res. 2016;17:35.

58. Balenga NA, et al. A fungal protease allergen provokes airway hyper-responsiveness in asthma. Nat Commun. 2015;6:6763.

59. Namvar $\mathrm{S}$, et al. Aspergillus fumigatus proteases, Asp f 5 and Asp f 13, are essential for airway inflammation and remodelling in a murine inhalation model. Clin Exp Allergy. 2015;45(5):982-993.

60. Boitano $S$, et al. Alternaria alternata serine proteases induce lung inflammation and airway epithelial cell activation via PAR2. Am J Physiol Lung Cell Mol Physiol. 2011;300(4):L605-L614.

61. Snelgrove RJ, et al. Alternaria-derived serine protease activity drives IL-33-mediated asthma exacerbations. J Allergy Clin Immunol. 2014;134(3):583-592.e6.

62. Castanhinha S, et al. Pediatric severe asthma with fungal sensitization is mediated by steroid-resistant IL-33. J Allergy Clin Immunol. 2015;136(2):312-322.e7.

63. Sly PD, Kusel M, Holt PG. Do early-life viral infections cause asthma? J Allergy Clin Immunol. 2010;125(6):1202-1205.

64. Taussig LM, Wright AL, Holberg CJ, Halonen M, Morgan WJ, Martinez FD. Tucson Children's Respiratory Study: 1980 to present. JAllergy Clin Immunol. 2003;111(4):661-675.

65. Edwards MR, Strong K, Cameron A, Walton RP, Jackson DJ, Johnston SL. Viral infections in allergy and immunology: how allergic inflammation influences viral infections and illness. J Allergy Clin Immunol. 2017;140(4):909-920.

66. Edwards MR, et al. The potential of anti-infectives and immunomodulators as therapies for asthma and asthma exacerbations. Allergy. 2018;73(1):50-63.

67. Jartti T, Gern JE. Role of viral infections in the development and exacerbation of asthma in children. JAllergy Clin Immunol. 2017;140(4):895-906.

68. Jackson DJ, et al. IL-33-dependent type 2 inflammation during rhinovirus-induced asthma exacerbations in vivo. Am J Respir Crit Care Med. 2014;190(12):1373-1382.

69. Liu L, et al. Association between rhinovirus wheezing illness and the development of childhood asthma: a meta-analysis. BMJOpen. 2017;7(4):e013034.

70. Lemanske RF, et al. Rhinovirus illnesses during infancy predict subsequent childhood wheezing. JAllergy Clin Immunol. 2005;116(3):571-577.

71. Stein RT, et al. Respiratory syncytial virus in early life and risk of wheeze and allergy by age 13 years. Lancet. 1999;354(9178):541-545.

72. Henderson J, Hilliard TN, Sherriff A, Stalker D, Al Shammari N, Thomas HM. Hospitalization for RSV bronchiolitis before 12 months of age and subsequent asthma, atopy and wheeze: a longitudinal birth cohort study. Pediatr Allergy Immunol. 2005;16(5):386-392.

73. Thomsen SF, et al. Exploring the association between severe respiratory syncytial virus infection and asthma: a registry-based twin study. $A m$ J Respir Crit Care Med. 2009;179(12):1091-1097.

74. Rubner FJ, et al. Early life rhinovirus wheezing 
allergic sensitization, and asthma risk at adolescence. J Allergy Clin Immunol. 2017;139(2):501-507.

75. Perez Ramirez L, et al. High number of early respiratory infections in association with allergic sensitization to mold promotes childhood asthma. JAllergy Clin Immunol. 2018;141(5):1921-1924.e4.

76. Beigelman A, Rosas-Salazar C, Hartert TV. Childhood asthma: is it all about bacteria and not about viruses? A pro/con debate. J Allergy Clin Immunol Pract. 2018;6(3):719-725.

77. Blanken MO, et al. Respiratory syncytial virus and recurrent wheeze in healthy preterm infants. N Engl J Med. 2013;368(19):1791-1799.

78. Heymann PW, et al. Rhinovirus infection results in stronger and more persistent genomic dysregulation: evidence for altered innate immune response in asthmatics at baseline, early in infection, and during convalescence. PLoS One. 2017;12(5):e0178096.

79. Beale J, et al. Rhinovirus-induced IL-25 in asthma exacerbation drives type 2 immunity and allergic pulmonary inflammation. Sci Transl Med. 2014;6(256):256ra134

80. Han M, et al. The innate cytokines IL-25, IL-33, and TSLP cooperate in the induction of type 2 innate lymphoid cell expansion and mucous metaplasia in rhinovirus-infected immature mice. JImmunol. 2017;199(4):1308-1318.

81. Hong JY, et al. Neonatal rhinovirus induces mucous metaplasia and airways hyperresponsiveness through IL-25 and type 2 innate lymphoid cells. J Allergy Clin Immunol. 2014;134(2):429-439.

82. Wark PA, et al. Asthmatic bronchial epithelial cells have a deficient innate immune response to infection with rhinovirus. J Exp Med. 2005;201(6):937-947.

83. Sykes A, et al. Rhinovirus 16 -induced IFN- $\alpha$ and IFN- $\beta$ are deficient in bronchoalveolar lavage cells in asthmatic patients. J Allergy Clin Immunol. 2012;129(6):1506-1514.e6.

84. $\mathrm{Zhu}$ J, et al. Bronchial mucosal IFN- $\alpha / \beta$ and pattern recognition receptor expression in patients with experimental rhinovirus-induced asthma exacerbations. J Allergy Clin Immunol. 2019;143(1):114-125.e4.

85. Zhivaki D, et al. Respiratory syncytial virus infects regulatory $\mathrm{B}$ cells in human neonates via chemokine receptor CX3CR1 and promotes lung disease severity. Immunity. 2017;46(2):301-314.

86. Stier MT, et al. Respiratory syncytial virus infection activates IL-13-producing group 2 innate lymphoid cells through thymic stromal lymphopoietin. J Allergy Clin Immunol. 2016;138(3):814-824.e11.

87. Krishnamoorthy N, et al. Early infection with respiratory syncytial virus impairs regulatory $\mathrm{T}$ cell function and increases susceptibility to allergic asthma. Nat Med. 2012;18(10):1525-1530.

88. Holtzman MJ. Asthma as a chronic disease of the innate and adaptive immune systems responding to viruses and allergens. JClin Invest. 2012;122(8):2741-2748.

89. Restori KH, Srinivasa BT, Ward BJ, Fixman ED. Neonatal immunity, respiratory virus infections, and the development of asthma. Front Immunol. 2018;9:1249.

90. Bønnelykke K, et al. Cadherin-related family member 3 genetics and rhinovirus $C$ respi- ratory illnesses. Am J Respir Crit Care Med. 2018;197(5):589-594.

91. Ahn K. The role of air pollutants in atopic dermatitis. J Allergy Clin Immunol. 2014;134(5):993999; discussion 1000

92. Khilnani GC, Tiwari P. Air pollution in India and related adverse respiratory health effects: past, present, and future directions. Curr Opin Pulm Med. 2018;24(2):108-116.

93. Cohen AJ, et al. Estimates and 25-year trends of the global burden of disease attributable to ambient air pollution: an analysis of data from the Global Burden of Diseases Study 2015. Lancet. 2017;389(10082):1907-1918.

94. Guan WJ, Zheng XY, Chung KF, Zhong NS. Impact of air pollution on the burden of chronic respiratory diseases in China: time for urgent action. Lancet. 2016;388(10054):1939-1951.

95. Wu W, Jin Y, Carlsten C. Inflammatory health effects of indoor and outdoor particulate matter. JAllergy Clin Immunol. 2018;141(3):833-844.

96. Gligorovski S, Abbatt JPD. An indoor chemical cocktail. Science. 2018;359(6376):632-633.

97. Berger K, Eskenazi B, Balmes J, Holland N, Calafat AM, Harley KG. Associations between prenatal maternal urinary concentrations of personal care product chemical biomarkers and childhood respiratory and allergic outcomes in the CHAMACOS study. Environ Int. 2018;121(pt 1):538-549.

98. Kim EH, et al. Exposure to phthalates and bisphenol A are associated with atopic dermatitis symptoms in children: a time-series analysis. Environ Health. 2017;16(1):24.

99. Araki A, et al. Associations between allergic symptoms and phosphate flame retardants in dust and their urinary metabolites among school children. Environ Int. 2018;119:438-446.

100.Meng G, Nie Z, Feng Y, Wu X, Yin Y, Wang Y. Typical halogenated persistent organic pollutants in indoor dust and the associations with childhood asthma in Shanghai, China. Environ Pollut. 2016;211:389-398.

101.Lewis AC. The changing face of urban air pollution. Science. 2018;359(6377):744-745.

102. Traffic-related air pollution: a critical review of the literature on emissions, exposure, and health effects - Special Report 17. Health Effects Institute. https://www.healtheffects.org/publication/ traffic-related-air-pollution-critical-review-literature-emissions-exposure-and-health. Published January 13, 2010. Acessed January 9, 2019.

103. Brandt EB, Myers JM, Ryan PH, Hershey GK. Air pollution and allergic diseases. Curr Opin Pediatr. 2015;27(6):724-735

104.Perez L, et al. Chronic burden of near-roadway traffic pollution in 10 European cities (APHEKOM network). Eur Respir J. 2013;42(3):594-605.

105. Appatova AS, Ryan PH, LeMasters GK, Grinshpun SA. Proximal exposure of public schools students to major roadways: a nationwide US survey. JEnviron Plann Man. 2008;51(5):631-646.

106.Grinshpun SA, Yermakov M, Reponen T, Simmons M, LeMasters GK, Ryan PH. Traffic particles in ambient air of a major US urban area: has anything changed over a decade? Aerosol Air Qual Res. 2014;14(5):1344-1351.

107. Ji H, Biagini Myers JM, Brandt EB, Brokamp C, Ryan PH, Khurana Hershey GK. Air pollution, epigenetics, and asthma. Allergy Asthma Clin Immunol. 2016;12:51.

108. Bowatte G, et al. The influence of childhood traffic-related air pollution exposure on asthma, allergy and sensitization: a systematic review and a meta-analysis of birth cohort studies. Allergy. 2015;70(3):245-256.

109. Bowatte $\mathrm{G}$, et al. Traffic-related air pollution exposure is associated with allergic sensitization, asthma, and poor lung function in middle age. JAllergy Clin Immunol. 2017;139(1):122-129.e1.

110. McCreanor J, et al. Respiratory effects of exposure to diesel traffic in persons with asthma. $N$ Engl JMed. 2007;357(23):2348-2358.

111. Khreis H, Kelly C, Tate J, Parslow R, Lucas K, Nieuwenhuijsen M. Exposure to traffic-related air pollution and risk of development of childhood asthma: a systematic review and meta-analysis. Environ Int. 2017;100:1-31.

112. Chen Z, Salam MT, Eckel SP, Breton CV, Gilliland FD. Chronic effects of air pollution on respiratory health in Southern California children: findings from the Southern California Children's Health Study. J Thorac Dis. 2015;7(1):46-58.

113. Jung DY, et al. Effect of traffic-related air pollution on allergic disease: results of the Children's Health and Environmental Research. Allergy Asthma Immunol Res. 2015;7(4):359-366.

114. Brunst KJ, et al. Timing and duration of traffic-related air pollution exposure and the risk for childhood wheeze and asthma. Am J Respir Crit Care Med. 2015;192(4):421-427.

115. Ryan PH, et al. Exposure to traffic-related particles and endotoxin during infancy is associated with wheezing at age 3 years. Am J Respir Crit Care Med. 2009;180(11):1068-1075.

116. Ryan $\mathrm{PH}$, et al. Is it traffic type, volume, or distance? Wheezing in infants living near truck and bus traffic. J Allergy Clin Immunol. 2005;116(2):279-284.

117. Sucharew H, et al. Exposure to traffic exhaust and night cough during early childhood: the CCAAPS birth cohort. Pediatr Allergy Immunol. 2010;21(2 pt 1):253-259.

118. Codispoti CD, et al. Traffic pollution is associated with early childhood aeroallergen sensitization. Ann Allergy Asthma Immunol. 2015;114(2):126-133.

119. Gruzieva O, et al. Traffic-related air pollution and development of allergic sensitization in children during the first 8 years of life. JAllergy Clin Immunol. 2012;129(1):240-246.

120. Mölter A, et al. A multicentre study of air pollution exposure and childhood asthma prevalence: the ESCAPE project. Eur Respir J. 2015;45(3):610-624.

121. De Grove KC, Provoost S, Brusselle GG, Joos GF, Maes T. Insights in particulate matter-induced allergic airway inflammation: focus on the epithelium. Clin Exp Allergy. 2018;48(7):773-786.

122. Oteros J, et al. Artemisia pollen is the main vector for airborne endotoxin. J Allergy Clin Immunol. 2019;143(1):369-377.e5.

123. Gour N, et al. Unique pulmonary immunotoxicological effects of urban PM are not recapitulated solely by carbon black, diesel exhaust or coal fly ash. Environ Res. 2018;161:304-313.

124.Zuo L, Otenbaker NP, Rose BA, Salisbury KS. Molecular mechanisms of reactive oxygen spe- 
cies-related pulmonary inflammation and asthma. Mol Immunol. 2013;56(1-2):57-63.

125. Li YJ, Kawada T, Azuma A. Nrf2 is a protective factor against oxidative stresses induced by diesel exhaust particle in allergic asthma. Oxid Med Cell Longev. 2013;2013:323607.

126. Li N, et al. A work group report on ultrafine particles (American Academy of Allergy, Asthma \& Immunology): why ambient ultrafine and engineered nanoparticles should receive special attention for possible adverse health outcomes in human subjects. J Allergy Clin Immunol. 2016;138(2):386-396.

127. London NR, Tharakan A, Rule AM, Lane AP, Biswal S, Ramanathan M. Air pollutant-mediated disruption of sinonasal epithelial cell barrier function is reversed by activation of the Nrf2 pathway. J Allergy Clin Immunol. 2016;138(6):1736-1738.e4.

128. Loxham M, Davies DE. Phenotypic and genetic aspects of epithelial barrier function in asthmatic patients. J Allergy Clin Immunol. 2017;139(6):1736-1751.

129.Zhao R, et al. Nasal epithelial barrier disruption by particulate matter $\leq 2.5 \mu \mathrm{m}$ via tight junction protein degradation. JAppl Toxicol. 2018;38(5):678-687.

130. Brandt EB, et al. Exposure to allergen and diesel exhaust particles potentiates secondary allergen-specific memory responses, promoting asthma susceptibility. JAllergy Clin Immunol. 2015;136(2):295-303.e7.

131. Salvi S, et al. Acute inflammatory responses in the airways and peripheral blood after shortterm exposure to diesel exhaust in healthy human volunteers. Am J Respir Crit Care Med. 1999;159(3):702-709.

132. Behndig AF, et al. Airway antioxidant and inflammatory responses to diesel exhaust exposure in healthy humans. Eur RespirJ. 2006;27(2):359-365.

133. Nordenhäll C, Pourazar J, Ledin MC, Levin JO, Sandström T, Adelroth E. Diesel exhaust enhances airway responsiveness in asthmatic subjects. Eur Respir J. 2001;17(5):909-915.

134. Weng CM, et al. Aryl hydrocarbon receptor activation by diesel exhaust particles mediates epithelium-derived cytokines expression in severe allergic asthma. Allergy. 2018;73(11):2192-2204.

135. Gras D, et al. Human bronchial epithelium orchestrates dendritic cell activation in severe asthma. Eur Respir J. 2017;49(3):1602399.

136. Bleck B, Tse DB, Gordon T, Ahsan MR, Reibman J. Diesel exhaust particle-treated human bronchial epithelial cells upregulate Jagged-1 and OX40 ligand in myeloid dendritic cells via thymic stromal lymphopoietin. J Immunol. 2010;185(11):6636-6645.

137. Tindemans I, et al. Notch signaling in $\mathrm{T}$ cells is essential for allergic airway inflammation, but expression of the Notch ligands Jagged 1 and Jagged 2 on dendritic cells is dispensable. J Allergy Clin Immunol. 2017;140(4):1079-1089.

138. Xia M, Harb H, Saffari A, Sioutas C, Chatila TA. A Jagged 1-Notch 4 molecular switch mediates airway inflammation induced by ultrafine particles. JAllergy Clin Immunol. 2018;142(4):1243-1256.e17.

139. Massoud AH, Charbonnier LM, Lopez D, Pellegrini M, Phipatanakul W, Chatila TA. An asthma-associated IL4R variant exacerbates airway inflammation by promoting conversion of regulatory T cells to TH17-like cells. Nat Med. 2016;22(9):1013-1022.

140. Rosa-Rosa L, Zimmermann N, Bernstein JA, Rothenberg ME, Khurana Hershey GK. The R576 IL-4 receptor $\alpha$ allele correlates with asthma severity. J Allergy Clin Immunol. 1999;104(5):1008-1014.

141. Brandt EB, et al. Diesel exhaust particle induction of IL-17A contributes to severe asthma. J Allergy Clin Immunol. 2013;132(5):1194-1204.e2.

142. Brandt EB, Khurana Hershey GK. A combination of dexamethasone and anti-IL-17A treatment can alleviate diesel exhaust particle-induced steroid insensitive asthma. JAllergy Clin Immunol. 2016;138(3):924-928.e2.

143. Kudo M, et al. IL-17A produced by $\alpha \beta$ T cells drives airway hyper-responsiveness in mice and enhances mouse and human airway smooth muscle contraction. Nat Med. 2012;18(4):547-554.

144.Irvin C, et al. Increased frequency of dual-positive TH2/TH17 cells in bronchoalveolar lavage fluid characterizes a population of patients with severe asthma. J Allergy Clin Immunol. 2014;134(5):1175-1186.e7.

145. Wang YH, et al. A novel subset of CD4(+) T(H)2 memory/effector cells that produce inflammatory IL-17 cytokine and promote the exacerbation of chronic allergic asthma. J Exp Med. 2010;207(11):2479-2491.

146. Hall SL, et al. IL-17A enhances IL-13 activity by enhancing IL-13-induced signal transducer and activator of transcription 6 activation. J Allergy Clin Immunol. 2017;139(2):462-471.e14.

147. Gour N, Wills-Karp M. IL-4 and IL-13 signaling in allergic airway disease. Cytokine. 2015;75(1):68-78.

148. Luyten LJ, et al. Air pollution and the fetal origin of disease: a systematic review of the molecular signatures of air pollution exposure in human placenta. Environ Res. 2018;166:310-323.

149. Lenberg J, Qian Q, Sun Z, Alam R, Gorska MM. Pre-pregnancy exposure to diesel exhaust predisposes offspring to asthma through IL-1 $\beta$ and IL-17A. JAllergy Clin Immunol. 2018;141(3):1118-1122.e3.

150. Manners S, Alam R, Schwartz DA, Gorska MM. A mouse model links asthma susceptibility to prenatal exposure to diesel exhaust. J Allergy Clin Immunol. 2014;134(1):63-72.

151. Fedulov AV, et al. Pulmonary exposure to particles during pregnancy causes increased neonatal asthma susceptibility. Am J Respir Cell Mol Biol. 2008;38(1):57-67.

152. GBD 2015 Tobacco Collaborators. Smoking prevalence and attributable disease burden in 195 countries and territories, 1990-2015: a systematic analysis from the Global Burden of Disease Study 2015. Lancet. 2017;389(10082):1885-1906.

153. Oberg M, Jaakkola MS, Woodward A, Peruga A, Prüss-Ustün A. Worldwide burden of disease from exposure to second-hand smoke: a retrospective analysis of data from 192 countries. Lancet. 2011;377(9760):139-146.

154.Lannerö E, Wickman M, van Hage M, Bergström A, Pershagen G, Nordvall L. Exposure to environmental tobacco smoke and sensitisation in children. Thorax. 2008;63(2):172-176.

155. Feleszko W, Ruszczyński M, Jaworska J, Strzelak
A, Zalewski BM, Kulus M. Environmental tobacco smoke exposure and risk of allergic sensitisation in children: a systematic review and meta-analysis. Arch Dis Child. 2014;99(11):985-992.

156. Saulyte J, Regueira C, Montes-Martínez A, Khudyakov P, Takkouche B. Active or passive exposure to tobacco smoking and allergic rhinitis, allergic dermatitis, and food allergy in adults and children: a systematic review and meta-analysis. PLoS Med. 2014;11(3):e1001611.

157. Chilmonczyk BA, et al. Association between exposure to environmental tobacco smoke and exacerbations of asthma in children. $N$ EnglJ Med.1993;328(23):1665-1669.

158. Burke H, et al. Prenatal and passive smoke exposure and incidence of asthma and wheeze: systematic review and meta-analysis. Pediatrics. 2012;129(4):735-744.

159. US Department of Health and Human Services. The Health Consequences of Smoking: 50 Years of Progress. A Report of the Surgeon General. Atlanta, Georgia, USA: Centers for Disease Control and Prevention; 2014.

160.Thacher JD, et al. Parental smoking and development of allergic sensitization from birth to adolescence. Allergy. 2016;71(2):239-248.

161. Biagini Myers JM, et al. Asking the right questions to ascertain early childhood secondhand smoke exposures. J Pediatr. 2012;160(6):1050-1051.

162.Vork KL, Broadwin RL, Blaisdell RJ. Developing asthma in childhood from exposure to secondhand tobacco smoke: insights from a meta-regression. Environ Health Perspect. 2007;115(10):1394-1400.

163. Gilliland FD, et al. Regular smoking and asthma incidence in adolescents. Am J Respir Crit Care Med. 2006;174(10):1094-1100.

164. Genuneit J, et al. Smoking and the incidence of asthma during adolescence: results of a large cohort study in Germany. Thorax. 2006;61(7):572-578.

165. Jaakkola MS, Piipari R, Jaakkola N, Jaakkola JJ. Environmental tobacco smoke and adult-onset asthma: a population-based incident case-control study. Am JPublic Health. 2003;93(12):2055-2060.

166. Mahabee-Gittens EM, Merianos AL, Matt GE. Preliminary evidence that high levels of nicotine on children's hands may contribute to overall tobacco smoke exposure. Tob Control. 2018;27(2):217-219.

167. Martins-Green M, et al. Cigarette smoke toxins deposited on surfaces: implications for human health. PLoS One. 2014;9(1):e86391.

168. Yu M, Mukai K, Tsai M, Galli SJ. Thirdhand smoke component can exacerbate a mouse asthma model through mast cells. J Allergy Clin Immunol. 2018;142(5):1618-1627.e9.

169.Vardavas CI, Filippidis FT, Agaku IT. Determinants and prevalence of e-cigarette use throughout the European Union: a secondary analysis of 26566 youth and adults from 27 Countries. To $b$ Control. 2015;24(5):442-448.

170.Zhu SH, Zhuang YL, Wong S, Cummins SE, Tedeschi GJ. E-cigarette use and associated changes in population smoking cessation: evidence from US current population surveys. $B M J$. 2017;358:j3262.

171. Wang MP, Ho SY, Leung LT, Lam TH. Electronic cigarette use and its association with smoking in 
Hong Kong Chinese adolescents. Addict Behav. 2015;50:124-127.

172. Cooke A, Fergeson J, Bulkhi A, Casale TB. The electronic cigarette: the good, the bad, and the ugly. JAllergy Clin Immunol Pract. 2015;3(4):498-505.

173. Hajek P, Etter JF, Benowitz N, Eissenberg T, McRobbie H. Electronic cigarettes: review of use, content, safety, effects on smokers and potential for harm and benefit. Addiction . 2014;109(11):1801-1810.

174. Clapp PW, Jaspers I. Electronic cigarettes: their constituents and potential links to asthma. Curr Allergy Asthma Rep. 2017;17(11):79.

175. Choi K, Bernat D. E-cigarette use among Florida youth with and without asthma. Am J Prev Med. 2016;51(4):446-453.

176. Schweitzer RJ, Wills TA, Tam E, Pagano I, Choi K. E-cigarette use and asthma in a multiethnic sample of adolescents. Prev Med. 2017;105:226-231.

177. Lim HB, Kim SH. Inhallation of e-cigarette cartridge solution aggravates allergen-induced airway inflammation and hyper-responsiveness in mice. Toxicol Res. 2014;30(1):13-18.

178. Strzelak A, Ratajczak A, Adamiec A, Feleszko W. Tobacco smoke induces and alters immune responses in the lung triggering inflammation, allergy, asthma and other lung diseases: a mechanistic review. Int J Environ Res Public Health . 2018;15(5):E1033.

179. Lawal AO. Diesel exhaust particles and the induction of macrophage activation and dysfunction. Inflammation. 2018;41(1):356-363.

180. Shan M, et al. Cigarette smoke induction of osteopontin (SPP1) mediates T(H)17 inflammation in human and experimental emphysema. Sci Transl Med. 2012;4(117):117ra9.

181. Hong MJ, et al. Protective role of $\gamma \delta \mathrm{T}$ cells in cigarette smoke and influenza infection. Mucosal Immunol. 2018;11(3):894-908.

182. Nakamura Y, et al. Cigarette smoke extract induces thymic stromal lymphopoietin expression, leading to $\mathrm{T}(\mathrm{H}) 2$-type immune responses and airway inflammation. J Allergy Clin Immunol. 2008;122(6):1208-1214.

183. Kearley J, et al. Cigarette smoke silences innate lymphoid cell function and facilitates an exacerbated type I interleukin-33-dependent response to infection. Immunity. 2015;42(3):566-579.

184.Lanckacker EA, et al. Short cigarette smoke exposure facilitates sensitisation and asthma development in mice. Eur Respir J. 2013;41(5):1189-1199. 185. Cayrol C, et al. Environmental allergens induce allergic inflammation through proteolytic maturation of IL-33. Nat Immunol. 2018;19(4):375-385.

186. Ferrini M, et al. Prenatal tobacco smoke exposure predisposes offspring mice to exacerbated allergic airway inflammation associated with altered innate effector function. Part Fibre Toxicol. 2017;14(1):30.

187. Singh SP, et al. Prenatal secondhand cigarette smoke promotes Th2 polarization and impairs goblet cell differentiation and airway mucus formation. J Immunol. 2011;187(9):4542-4552.

188. Feleszko W, et al. Parental tobacco smoking is associated with augmented IL-13 secretion in children with allergic asthma. J Allergy Clin Immunol. 2006;117(1):97-102.

189. Singh SP, et al. Gestational exposure to sidestream (secondhand) cigarette smoke promotes transgenerational epigenetic transmission of exacerbated allergic asthma and bronchopulmonary dysplasia. JImmunol. 2017;198(10):3815-3822.

190.Christensen S, et al. Prenatal environmental tobacco smoke exposure increases allergic asthma risk with methylation changes in mice. Environ Mol Mutagen. 2017;58(6):423-433.

191. Yang IV, Lozupone CA, Schwartz DA. The environment, epigenome, and asthma. JAllergy Clin Immunol. 2017;140(1):14-23. 